\title{
THE IMPACT OF VIRTUAL MONEY ON E-COMMERCE
}

\section{Mirela Redžović, Jelena Novaković}

Singidunum University, 32 Danijelova Street, Belgrade, Serbia
Correspondence:

Mirela Redžović

e-mail:

mirela.redzovic.12@singimail.rs

\begin{abstract}
:
The concept of E-business, along with E-commerce, has been developed due to the expansion of communications system. The concept of E-commerce has first appeared in the 1970s. E-commerce represents a portion of electronic commerce, being a multidisciplinary concept of trading in products and services, as well as paying for them, using the Internet via virtual market. E-commerce has expanded on a global level significantly during the last decade, and it still shows great potential in growth and development. One of immediate consequences of growth of electronic commerce is a greater need for a type of virtual money that can be used as an instrument of payment. The year 2009 marked the appearance of a revolutionary virtual currency named Bitcoin, a decentralized digital cryptocurrency. Bitcoin is actually the first virtual currency that has gained the trust of its users and in that way managed not only to survive, but to secure a significant presence in the place of online market transactions. This paper aims to point out both positive and negative effects of Bitcoin on e-commerce, as well as its influence on the greater macroeconomic and political plan.
\end{abstract}

Key words:

e-commerce, virtual money, bitcoin, impact.

\section{INTRODUCTION}

E-commerce represents a portion of electronic commerce, being a multidisciplinary concept of trading in products and services, as well as paying for them, using the Internet via virtual market. E-commerce has expanded on a global level significantly during the last decade, and it still shows great potential in growth and development. One of the consequences of the growth of electronic commerce is the greater need for a sort of virtual money that can be used as an instrument of payment. In this paper we will represent the main problem about the impact of virtual money on Ecommerce. The year 2009 marked the appearance of a revolutionary virtual currency named Bitcoin, a decentralized digital cryptocurrency. Bitcoin is actually the first virtual currency that has gained the trust of its users and in that way managed not only to survive, but to secure a significant presence in the place of online market transactions. There wes a virtual currency, before Bitcoin, which was used only in gambling, betting and video games. This paper aims to point out both the good and bad aspects of influence Bitcoin has on E-commerce, as well as its influence on the greater macroeconomic and political scheme of things. The subject of 
the paper is the use of a virtual currency in electronic commerce. The first part of the paper will expound the general characteristics of electronic commerce, including its development. The second part will deal with the digital cryptocurrency, Bitcoin, the operating process and transfers, while the positive and negative effects of virtual currencies and the future of electronic commerce itself will be explained in the final, third part.

\section{ELECTRONIC COMMERCE}

E-commerce has developed due to the process of globalization and the Internet. The advent of a website called Amazon.com in 1995, gave way to the appearance of electronic commerce. In it is early stages, Amazon only sold books while CDs and DVDs came later on. To this day, Amazon serves as a world leading e-commerce website. E-commerce can be defined as a commercial transaction between the provider and consumer of goods, based on an online digital technology. It is based on modern telecommunication, computer science, information technology and cryptology. E-commerce is actually a part of E-business. The global significance of electronic commerce lies in its easy access, with no limitations in regard to time or space. Access to commerce can be gained no matter where the user is, as long as they are using a computer. E-business technology is able to provide easy access to suppliers, prices and terms of shipment of any product. Because of the existence of E-commerce, product prices have become lower thanks to the smaller costs of online business as well as the presence of a huge variety of products.

The most common five types of E-commerce are presented in Table 1.

\begin{tabular}{cl}
\hline \multicolumn{2}{c}{ Types of e - commerce } \\
\hline $\begin{array}{c}\text { B2C - Business to } \\
\text { Consumer }\end{array}$ & $\begin{array}{l}\text { Selling of products to buyers - } \\
\text { Retail (Amazon.com) }\end{array}$ \\
\hline $\begin{array}{c}\text { B2B - Business to } \\
\text { business }\end{array}$ & $\begin{array}{l}\text { Trade between companies } \\
\text { (eSteel) }\end{array}$ \\
\hline $\begin{array}{c}\text { C2C - Consumer } \\
\text { to Consumer }\end{array}$ & $\begin{array}{l}\text { Trade between consumers } \\
\text { (Limundo.com) }\end{array}$ \\
\hline P2P - Peer to Peer & $\begin{array}{l}\text { Online information exchange } \\
\text { without an intermediary } \\
\text { (Bitcoin) }\end{array}$ \\
\hline M-commerce & Transactions via cell phones \\
\hline
\end{tabular}

Table 1. Five common types of E-commerce
The size of E-commerce equates to the size of online population, which amounted to 3,3 billion users, a staggering $40 \%$ of the world population in 2015 . Since the online population is rapidly growing, the growth of $\mathrm{E}$ commerce is considered imminent. It is estimated that by 2050 the whole of global commerce will convert to E-commerce.

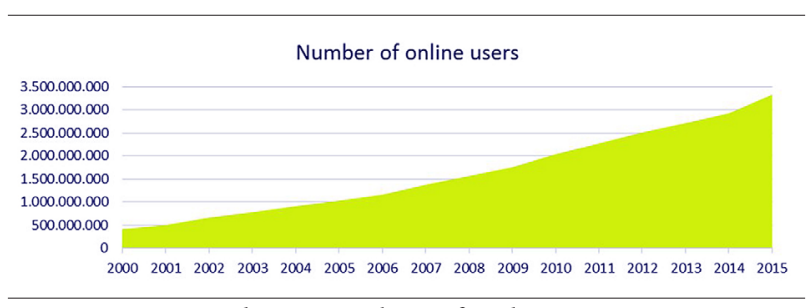

Graph 1. Number of online users

\section{BITCOIN}

The production of money started with golden coins. Due to the impracticality of payment in coins, banks started handing out gold receipts as proof of the existence of golden coins in the bank vaults. Furthermore, Fiat money was introduced, intrinsically valueless money used as money because of government regulation and thanks to that, it could be used in transactions and valued by the amount of numbers written on the paper. Moreover, this money had not gold reserve, and actual value. So it did not inspire citizens' trust. However it's still used these days and nobody is questioning whether that is a good or a bad thing. E-money exists thanks to the development of information technology and the growth of E-business.

Electronic (or digital) money signifies the consequence of the growth of E-business. E-money is an innovation that is currently in its early phase of development, but it already strives to assert dominance in the future, as in becoming the primary instrument of payment and perhaps completely replace paper money as well as other noncommercial instruments such as checks. Its use is far more practical in payment and transfers. Business banks are issuers of electronic money which is used in online payments. It has the same characteristics as paper money, and its usage is anonymous. The development of E-money depends primarily on the willingness of beneficiaries to accept new technology and readiness to pay the fee of usage.

Bitcoin currency has been launched in 2009 under the pseudonym of Satoshi Nakamoto. It is assumed that companies such as Toshiba, Samsung, Nakamichi and Motorola stand behind the pseudonym. Bitcoin represents a virtual cryptocurrency, an effect of the digital age, 
based on open source peer-to-peer internet protocol. The base idea is the same as in Fiat money, i.e. to make payment easier and to provide a universal currency that can be applied worldwide. Furthermore, it is a private currency without the central monetary authority that is in charge of overseeing the currency. Moreover, cryptography is the protection mechanism of the currency. Finally, Bitcoin network consists of a great number of computers, where a single computer acts as a node in the network.

Bitcoin can be acquired in two possible ways: via mining or via buying:

- Mining - Miners represent group of computers that are joined together in order to create a bigger operational strength in solving complicated mathematical problems. It leads to a more efficient and a faster way of acquiring new Bitcoins.

- Buying Bitcoins - Buying Bitcoins serves as a traditional way of currency converting via Ecurrency exchange. There are two ways they can be bought: from an individual or from stock exchange. Buying from an individual is simple and it is performed on the Localbitcoins.com website, which includes Serbia, meaning that Serbian dinars can be exchanged for Bitcoins. Buying Bitcoins from stock exchange is expensive and it's a much more complicated process. Commission fees are high, considering that Bitcoins can only be acquired using dollars this way. The most famous world stock exchange that sells Bitcoins is Bitstamp. Currently, 1 Bitcoin $($ BTC) = $373.31 \$$.

\section{Bitcoin Transfer}

In order to get their own personal digital wallet, an E-wallet, Bitcoin users must register on an official website. E-wallet is software that the user installs on their device, whether it is a computer or a smart phone. The user with it contains a unique Bitcoin address or a bar code that's made up of 32 numbers and letters - similarly to a bank account.

If the user wants to make a Bitcoin transaction, the transfer gives them a warrant transaction, similarly to sending e-mails, except that instead of an e-mail address, the user uses their unique Bitcoin address as well as their private transfer key. The private transfer key is a secret code, known only to the user, completely obscure to others. The transfer is made by using a digital signature. A digital signature is made of an asymmetric encryption and a public and private key and is sent via encrypted file until it is incorporated into a block, which is then incorporated into a chain, and the user gets the notification that their Bitcoin transfer has been successful.

\section{IMPACT OF VIRTUAL MONEY}

The upside of Bitcoin as a virtual currency is that it increases the total number of electronic commerce service users. Young people are being introduced with the process of electronic transactions in a fun and innovative way, which is a good thing. Another good thing is that there is no intermediary in the transaction process, meaning that

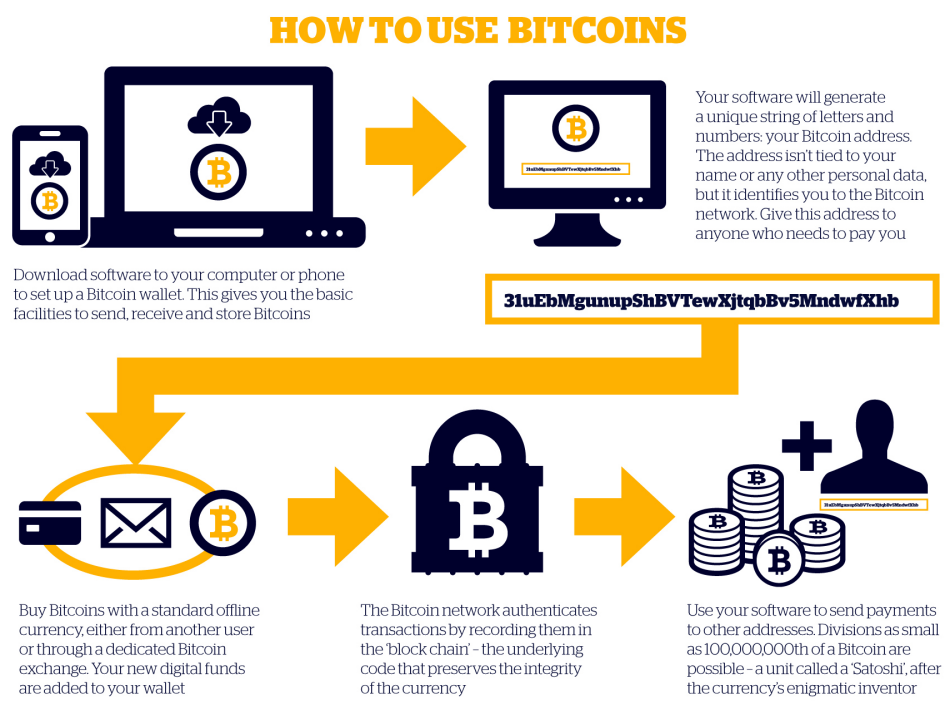

Picture 1. How to use Bitcoins; www.canadabitcoinpharmacy.com 
the transactions are safe. The entire system is defined by an original algorithm that can not be changed by anybody. Many of the world's big companies, such as Microsoft, Victoria's Secret, Amazon, Subway, Apple, Tesla etc., have accepted this currency as an instrument of payment.

The bad side of Bitcoin is that it is a deflationary currency. Its exchange rate is fluctuating, and stirring stock speculations. It is traded in order to make a profit on spread. Furthermore, without a central authority to supervise the currency and its transactions, crime has become a problem and Bitcoins have frequently been used to finance illegal services and commodities. As it is mentioned, there is no trust in the currency. Moreover, absence of regulation is the obstacle in wider acceptance of the currency.

People usually do not pay attention on safe side of the currency. This question is easily understood by looking back at 1971, USA, when President Richard Nixon ended the convertibility of the dollar into gold, making the dollar a currency without safe coverage. Since that time, the dollar is virtually -a form of a virtual currency. In fact, currencies around the world are practically virtual money, but under control of central banks i.e. stability of prices and money in circulation is provided.

\begin{tabular}{ll}
\hline \multicolumn{2}{c}{ Virtual currency } \\
\hline Pros & Cons \\
\hline No intermediary & Deflationary currency \\
\hline Anonymity & $\begin{array}{l}\text { Malpractice in terms of } \\
\text { illegal transactions }\end{array}$ \\
\hline Transaction safety & $\begin{array}{l}\text { Absence of laws and } \\
\text { regulations }\end{array}$ \\
\hline
\end{tabular}

Table 2. The pros and cons of a virtual currency

Bitcoin features encourage people to think about earning big amount of money to an illegal way. Websites like Silk Road, Silk Road reloaded, Amora Marketplace and Evolution Marketplace represent illegal online markets that use Bitcoin as payment for illegal commodities and services. They were introduced at the same time as Bitcoin. Silk Road has been a number one website of the acquisition of illegal products and services online. Silk Road offers stolen products, illegal pornographic material, drugs, guns and even contract killing. It goes without saying that these markets are illegal and completely illegitimate. The US Federal court in Manhattan prosecuted the Silk Road website founder, Rose Ublert, confiscating 144,336 Bitcoins (31 million Euros). The website has been shut down, and Rose Ulbert found guilty, sentenced to life imprisonment. However, there are more websites that still continue to engage in illegal transactions.

\section{CONCLUSION}

This paper showed the development of electronic commerce in the last twenty years, as well as its prospects for further growth in the years to come. Considering the evaluated positive as well as negative impacts of Bitcon on E-commerce, it is the authors' opinion that this currency will not reach a greater global expansion in the market. Bitcoin may seem like a good replacement for real money, but it simply is not safe enough to be widely accepted. However, the authors consider that there will be an absolute need for virtual money as a result of technological development worldwide. Furthermore, the existence of the currency depends on organized institutional control of its issuance, rates and circulation. Finally, it is only in way that the currency will become globally accepted.

\section{Acknowledgment}

The work reported in this paper has been supported by prof. dr Lidija Barjaktarović, Singidunum University, Belgrade. The authors are grateful to her for her contribution to this paper.

\section{REFERENCES}

Đurđević D.,Stevanović M. (2015). Dehumanisation as a challenge to the information age economy. Synthesis 2015 - International Scientific Conference of IT and Business-Related Research, 16 - 17 April 2015 (pp 17-21), Belgrade, Serbia

Đurđević, D. (2014). Pranje novca: Plastični i virtuelni novac. Šesta naučna konferencija BISEC (Business Information SECurity), (pp 12-16), University Metropolitan, Belgrade.

FATF Report (2014). Virtual Currencies Key Definitions and Potential AML/CFT Risks, http://www.fatf-gafi.org/

Former Silk Road Task Force Agent Pleads Guilty to Money Laundering and Obstruction, https://www. fbi.gov/sanfrancisco/press-releases/2015/formersilk-road-task-force-agent-pleads-guilty-to-moneylaundering-and-obstruction

Guo J., Chow A. Virtual Money Systems: a Phenomenal Analysis. http://citeseerx.ist.psu.edu/viewdoc/down load?doi $=10.1 \cdot 1.449 .2221 \&$ rep $=$ rep $1 \&$ type $=$ pdf 
Končar J. (2003). Electronic commerce, Subotica, Univesity of Novi Sad, Faculty of economics

Milosavljević M., Mišković V. (2016). Electronic commerce, Belgrade, Singidunum University

Pavlović D. How does it workBitcoin. http://pravoikt.org/ kako-funkcionise-bitkoin/

Pavlović D. SilkRoad-Illegalonline market. http://pravoikt. org/put-svile-silk-road-zloupotreba-bitkoina-i-ilegalna-onlajn-trzista/
Simpson, B.P. (2014). Money, Banking, and the Business Cycle: Volume II: Remedies and Alternative Theories. (pp 161), Palgrave Macmillan, New York.

Tomić N. (2015).Comparative analysis of private and state electronic money. Synthesis 2015 - International Scientific Conference of IT and Business-Related Research, 16 - 17 April 2015 (pp 56-79), Belgrade, Serbia 